\title{
Encounters at the Counter: Gender and the Shopping Experience
}

\author{
Ayșe Durakbaşa and Dilek Cindoğlu
}

This chapter traces the feminisation of shopping in parallel with the rapid proliferation of shopping malls in Turkey since the 1980s. The masculine world of the traditional bazaar (charshi) has been gradually transformed with the emergence of the high-street department store since turn-of-the-century Ottoman modernisation. New shopping districts and promenades developed in the main cities of Turkey, especially after the 1960s, and shopping visits and window shopping became part of mainly middle-class housewives' routines. Gradually women's control over the household budget and consumption has increased in urban centres, because of the changing roles and tasks related to children and homemaking. One main focus is the inter-relationship between the change in the homemaking activities of women of the new middle classes and the rise of malls. We also describe how shoppers from different class backgrounds benefit from a web of shopping venues, ranging from the neighbourhood grocer, to open marketplaces, to malls and hypermarkets.

The malls and entertainment centres that have become centres of urban life and culture recently mark the development and accentuation of a distinctive taste among the upper classes and an increased socialisation in urban culture, especially among the youth of the lower classes.

The social atmosphere in these malls reflects both the fluidity of a postmodern consumption culture and the structural inequalities of class and gender. We describe the various dramas enacted between shoppers, shop assistants and shop managers, parallel with the changes in the organisation of the shop as a social setting. Hence the last section of the chapter looks at the work conditions of sales personnel as important actors in the shopping scene vis-à-vis shoppers.

\section{The rise of malls in urban Turkey}

In the 1980s, the process of economic liberalisation in Turkey led to a shift in previous policies of protectionist import substitution to a new development strategy 
based on the promotion of domestic export industries, and the encouragement of foreign investment. This has led Turkey to open up to the world socio-culturally as well as economically. Alongside these changes there has been a shift from scarcity to abundance in goods and services.

In the last decade, big cities witnessed the emergence of new malls and superstores, such as Ataköy Galleria (Istanbul, in 1988), Atakule (Ankara, in 1989), Karum (Ankara, in 1991), Metro (Ankara, in 1990), Kipa (Izmir, in 1994), Carrefour (Istanbul, in 1993), Carrousel (Istanbul, in 1995), Akmerkez (Istanbul, in 1995), Outlet Centre (Izmit, in 1997), Bauhaus (Istanbul, in 1996). These are ultra-modern buildings developed either in the heart of upper-middle-class neighbourhoods or on the outskirts of the city, which can be only reached by car. In both cases, these multi-storey constructions are welcoming yet intimidating to visitors, not only with expensive shops but also with luxurious interiors. The shining spotless marble floors contrast with the habitually dusty and muddy streets of Turkey. Most of the time these malls have food courts occupied by Western food chains, such as McDonalds and Burger King, along with Turkish döner kebab or sweetshops, where visitors can enjoy familiar food in a non-familiar setting.

An overview of the increasing activity of international retaiters in Turkey, starting from the late 1980s, suggests that Turkey became a desirable target for multinationals as a result of the new development strategy and its positive effects on the growth rate and per-capita income. Between 1985 and 1993, GNP per capita increased in real terms at an average annual rate of 3 percent. Turkey's demographic characteristics also made it favourable, especially for international food retailers. According to the latest census, Turkey has a population of more than 62 million, with an annual population increase rate of 2.2 percent. The population is young, especially compared with the ageing population in Europe (more than 60 percent of the population being below thirty years of age) (Tokatli and Boyaci, 1997, p.104). There is a high rate of urbanisation and an increasing concentration of the population in the main cities, such as Istanbul, Ankara, Izmir, Adana and Bursa. ${ }^{1}$ On the other hand, income distribution is skewed, giving some segments of the population great purchasing power. The richest 20 percent of the population takes more than half of the GNP, and is concentrated in the major cities. ${ }^{2}$

In 1990, 74.26 percent of Istanbul inhabitants, 70 percent of Ankara inhabitants and 60 percent of Izmir inhabitants had a stable income, whereas the proportion is 38.4 percent in Turkey as a whole. So there is a large group with considerable purchasing power who constitute the clientele of the new shopping sites (Sönmez,1996, pp.126-7). Thirty of Turkey's 52 hypermarkets are concentrated in Istanbul, and it is estimated that they cover 25 percent of the retail trade in Turkey and 50 percent of retail trade in Istanbul. The market is still unsaturated, and many foreign and domestic companies are planning to enter it (Sönmez, 1997). Visible material affluence exists alongside high population growth, rapid urbanisation, high inflation, unemployment, unequal income distribution and huge disparities between urban and rural life. Figures show that consumption has increased tremendously. ${ }^{3}$

In a cross-cultural study of materialism carried out by Ger and Belk (1990), it has been argued that individual-oriented materialism can go together with 
collectivist cultural orientation. Ger suggests that this explains especially the behaviour of Turkish female shoppers (p.189): 'If materialism is linked to enhancing the material well being of, and consumption for a unit that unit may be a single individual in some cultures, several individuals (close friends and family members) in other cultures' (p.190). There is a noticeable shift in consumption culture towards the materialistic, enhanced by incentives such as credit cards ${ }^{4}$ and the onslaught of images in advertising, as well as change in the consumption patterns of urban households, with women of all classes becoming more involved in handling the family budget. Women of all classes use a variety of outlets for shopping, especially for the needs of the family, and develop new skills to benefit from what each has to offer. The shopping scene is rich, with the outlct and its practices differing according to the type of goods sold, and with wide variety in outlet design and in the drama of the act of buying and selling.

\section{From the charshi to the mall}

The first observation about shopping in Turkey is the influence of a sex-segregated culture on shopping practices. The charshi - an element of the architectural planning of Ottoman town centres, composed of small shops directed by guild associations - is predominantly a male domain in which sellers and buyers are mostly men. The entry of women into this public domain as shoppers is a relatively recent phenomenon, and has been monitored by the family and the community quite closely. Women, as buyers, had very limited access to charshi, and would mostly have been accompanied by men, children or servants. The remnants of this practice are still prevalent in the provincial towns where the market continues to be a male-dominated space. Itinerant peddlers sometimes brought goods to the doorsteps of women customers. The bohçacı, or women pedlars, who visited housewives with bundles of embroidery, linen, garments and clothing - a practice that used to be considered a handy way of preparing the çeyiz, or trousseau, for young girls - was one of the main personages of the traditional mahalle (neighbourhood).

One can also draw a parallel between the lifestyle and cultural outlook of the charshi esnafi - the group culture of the small merchants and artisans - and the religious setting of the charshi itself (Saylı, 1992, p.16):

The relationship between the bazaar and the mosque in the construction of the Turkish cities cannot be overlooked. The overlap between work hours and prayer times made it necessary for the mosques to be built around the bazaar.

Işın (1985, p.541) lists three structuring elements in the traditional Ottoman life space: the mahalle, the charshi and the cami (the mosque or other religious buildings) and private housing areas. The charsh $i$ was the centre of commercial activities as well as the administrative offices of the esnaf, the tradesmen who manipulated a commercial network that extended beyond the borders of the empire. The consumption norms were defined by religious values until the nineteenth century, when this structure was challenged by imported Western goods which became symbols of social status (Işın, 1985. p.545). 
In the nineteenth century, parallel to the changes in the economic life and greater integration with Europe, specialised bazaars and traditional occupations lost their symbolic significance, and consumption norms and practices changed. Consumption patterns, previously homogeneous, shared by rich and poor in the classical Ottoman mahalle, proliferated according to the tastes of different social strata and status groups. The upper classes wanted to acquire the aesthetic objects (such as pianos and Western furniture) imported into Istanbul as signs of their social superiority over bureaucrats and other classes in the phase of modernisation (Işın, 1985, p.553).

In the second half of the nineteenth century a number of European retailers - such as Louvre, Au Lion, Bon Marché, Au Camelia, Bazar Allemand, Carlmann et Blumberg, Orosdi Back, Au Paon and Baker - opened department stores in the Ottoman capital and some other major cities of the empire. One of these grand, rich shops, Bon Marché, situated in Pera (the European district of Istanbul) became a standardised name for all similar shops catering to the needs and tastes of a rising Ottoman bourgeoisie (Toprak, 1995, p.27). Bon Marchés became part of late-nineteenth-century Ottoman daily life, as places where the upper classes had access to the Western goods in Galata and Pera. Many novels set in that period mention shopping trips of upper-class Ottoman women to Pera as a planned and special activity for the womenfolk of konak (mansion) households. Bon Marchés brought a new experience to shopping, in which the goods were sold not only for their utility but also to cater for the aesthetic needs of customers, starting with shop-window presentation. Consequently, window shopping and strolling in the streets became a pastime and leisure activity in late-nineteenth-century Istanbul. Whereas the traditional mahalle lost its homogeneity in living standards and lifestyles, the Beyoğlu and Pera districts emerged as centres of affluence in which an opulent lifestyle was on offer (Işın, 1985, pp.552-3). The split between Europeanised Pera, where the non-Muslim minorities were concentrated, and the Muslim neighbourhoods of the old city became sharper. One could observe the beginnings of the socioeconomic stratification of neighbourhoods in the years before and after the First World War. As Duben and Behar (1991, p.31) comment,

During the Young Turk period, a small number of wealthy, modern-minded Muslim families began to leave the traditional enclaves of those of their faith in intramural Istanbul for 'apartment life' (apartman hayatz), in the new neighbourhoods of Nişantaşı and Şişli, which lay north of traditional non-Muslim Pera. This flow continued through the war years and into the 1920s and 1930s. The war years were in many respects a watershed for segments of the old elite.

New habits of consumption, Bon Marché shopping trips, and westernised lifestyles accompanied the growth of a new upper class, an Ottoman bourgeoisie. The early examples of pedestrian arcades, usually called pasaj (from the French passage) - built in the form of arcades in Pera and later in Şişli-Nişantaşı, and in Kadıköy-Bahariye and Bağdat Caddesi on the Asian shore - were the first venues for window shopping for middle- and upper-class women in Istanbul in the midtwentieth century.

Compared to strolling in the mall of today, 'window shopping' in arcades was less welcoming and accessible, in that the pedestrian onlookers were not 
expected to touch goods unless they intended to buy them. Many conflicts arose between sales assistants and potential buyers when the latter handled goods. Even today, in city centres pedestrianised for commercial and cultural purposes the class characteristics of customers are likely to be more homogeneous than in malls. However, women are to be found as shoppers in both. In opposition to the charshi, where women were almost always excluded, the open-air markets had more space for women, both as buyers and sellers. Village women, as sellers of their own produce, always had a place in provincial peasant markets. The presence of women as vendors in the periodic open markets in urban centres is, however, a more recent phenomenon.

\section{The culture of consumption in contemporary Turkey: the web of shopping practices}

Urban life and culture in the 1990s were marked by the building of malls and entertainment centres in the big cities, and these sites have provided a social space for the development and accentuation of a distinct taste. Nevertheless, shopping is not a uniform experience, even for the upper classes. On the contrary, many different types of shopping outlet co-exist, and each offers a different set of advantages.

Malls - such as Akmerkez, Atakule, Karum and Capitol - are a relatively recent phenomenon in Turkey. In Akmerkez, awarded a prize for the most modern mall in Europe, a vast variety of tastes co-exist. For example, Burger King is next to more traditional Turkish fast food, such as döner kebab or sultanahmet köftecisi, and chocolate muffins and doughnuts are sold next to the Saray muhallebicisi, selling Turkish milk sweets and puddings. Not only the food, but the cleanliness of the floors, the standards of display, the cafes and even the bathrooms of these malls present ultra-modern, rich and luxurious environments that overwhelm visitors.

Before these malls arrived, Turkey did have individual department stores, such as Yeni Karamürsel and Gima, in which clothing, housewares and even sometimes food were sold under one roof. New outlets, such as Çarşi, Top Avenue and Marks \& Spencer, have been opened recently, and are likely to grow in number. Arcades have also existed in big cities for decades, and still have a function today in Beyoğlu, Kızılay, Tunalı Hilmi, Bahariye and Bağdat Caddesi, where a constellation of chain-stores exists.

Enormous hypermarkets, such as Migros, Carrefour, Metro and Beğendik, sell groceries, housewares and even basic clothing to the middle and uppermiddle classes, and are mainly family shopping sites. ${ }^{5}$ Supermarkets are smaller, and sell groceries for daily consumption. New chains of supermarkets, such as Ismar, have developed through co-operation between non-corporate indigenous entrepreneurs, and have built a widespread network across the country. In addition, neighbourhood-oriented big open markets have emerged to cater to the needs of a particular community, meeting the basic food and clothing needs of fixed-income groups. Neighbourhood groceries and pedlars, small grocery shops, butchers and greengrocers provide 'credit selling', ${ }^{6}$ a traditional credit 
system for the lower-middle classes. They provide convenience for the upper classes, who want goods delivered to their apartments: they order by phone, and have staples, such as newspapers, fresh bread, yogurt and milk, delivered by the apartment-block doorkeeper. In more traditional neighbourhoods, the grocer puts items into baskets hung from windows, in response to the customer's order.

Various forms of door-to-door selling or home visiting also exist. Along with the traditional bohçacı, mainly gypsy women, a more modern form has emerged in the last decades, aimed at urban women and practised by companies such as the German Avon and the Swedish Oriflame cosmetic companies. Oriflame had more than 70,000 representatives in Turkey in 1997, indicating the extent of the market and the acceptance of the practice among women. Oriflame is an example of successful international corporate marketing using the services of women in direct selling, thus spreading an ideology of money-making - additional income in the hands of women for their own consumption - as an indicator of success. ${ }^{7}$ Representatives provide catalogues and reach customers through networks of acquaintances. In the event of even the slightest dissatisfaction, a 'money-back guarantee' is provided. When a person wants to enter the network, she finds a representative who sponsors her, but she also has to pay an entrance fee. When the new salesperson starts, the sponsor receives a commission on all her sales. It is interesting to note that these are entrepreneurship practices that target women buyers. In a sex-segregated society like Turkey's, it is no surprise that all of these practices are flourishing and finding their niche.

Another contemporary version of the bohçacı is the so-called 'suitcase trader', again a case of women selling to women, this time clothing. It is often a mafiabased form of informal trade with Russia and Eastern European countries, and so it is women who act as conduits for this unrecorded international trade. This kind of trade also takes place in more individualised informal networks selling European fashion brands or non-European goods, such as Indian crafts or Japanese technology. The system sometimes involves a chain of intermediaries, sometimes a sole woman who travels to, say, Italy, gets the special orders, and brings them back to sell to customers in the immediate surroundings of either home or workplace.

Especially for lower classes, the main shopping venues are neighbourhood-based corner shops, grocers, greengrocers and butchers, touring vans, neighbourhood open markets or small-scale markets, or supermarkets. This is due to the limitations of transportation to the centre, and to hypermarkets, which are usually situated outside the city, and also due to the advantages of a personal credit system that operates between shopkeepers and their local customers.

Ayşe and Sencer Ayata's research into housing sites in Ankara shows that 40 percent of all the shopping needs in Zafertepe, a gecekondu neighbourhood are provided from neighbourhood-based shops. Also, in lower-class apartment-block neighbourhoods such as Abidinpaşa and Keçiören, shopping is neighbourhood based. In Abidinpaşa, the neighbourhood open market is the most popular shopping venue (37.8 percent), and in Keçiören the figure is 23.6 percent. According to the Ayatas' findings, there is an inverse correlation between the level of income and education and the choice of shopping in the neighbourhood. 
However, it is possible that in upper-class neighbourhoods close to the central shopping district both the high-priced neighbourhood shops providing a selection of specialities, such as charcuterie or patisserie, and the central shopping district are used more often than in suburban upper-class areas, whose residents do most of their shopping in malls (Ayata and Ayata, 1996, p.104).

Although the choice of shopping facilities differs according to social class, shoppers of the same class may benefit from shopping settings totally different in character. For example, in Etiler, an upper-middle-class district of Istanbul, both the luxurious up-market mall Akmerkez and Ulus Pazarı, an open market bazaar of a type known as a sosyete pazari ('high-society bazaar'), cater to the area's needs.

Neighbourhood-based shopping venues provide an informal setting, especially for lower-class housewives, and have comparative advantages over malls, hypermarkets, supermarkets and department stores. While such large-scale shopping units provide product diversity, the convenience of shopping with credit cards, 'one-stop' shopping, and are handy for working women and middle- and upper-class family shopping, neighbourhood bazaars and shops are more convenient for lower-class female shoppers.

The different forms of shopping discussed are not necessarily in competition with each other. On the contrary, depending on the needs of their individual users, each is used strategically and complementarily. There is a web of shopping practices in which the customer obtains goods formally or informally, with the service either of trained shop assistants in high-status department stores or of doorto-door salespeople, with their more familiar ways. All these shopping experiences have something in common: they claim to provide personalised, convenient and reliable service and a congenial shopping atmosphere, whether it is the chainstore's assistant helping a woman to buy a new coat, the Oriflame representative marketing a new lipstick, or the neighbourhood grocer sending a delivery person with a carton of milk to an apartment. Regardless of her social class, these forms of shopping make the shopper feel privileged and special. Although it might be argued that the interaction in the mall or department store is anonymous and less personalised, our interviews have showed us that upper-rank shop assistants and shop managers have remarkable interpersonal relations with their customers, and define their success in those terms.

\section{The changing role of women as shoppers}

The woman shopper has recently become the main actor on the shopping scene in contemporary Turkey. The traditional division of labour in household chores gives the responsibility of shopping to men, who are the main breadwinners and usually control the family budget. This practice is still prevalent in small cities and in traditional households in metropolitan areas. Among occupational groups, merchants, the owners of small businesses and farmers tend to retain the traditional pattern of male shopping, these men generally still being in control of all the money in the household. They use mainly open markets or hypermarkets. In such households, the male head of household decides what is to be cooked for the family and visitors. 
However, divisions of labour have gone through a transformation in urban areas, especially among the middle classes, whether the wife is employed or not. The rise of the new shopping venues has also transformed shopping practices for women, who have become more important in the making of the new middle-class lifestyle and in urban culture. As Öncü (1997, p.70) argues, 'The homogenising cultural flows of global consumerism have served to produce and re-produce cultural fragmentation at the local level in contemporary Istanbul'. Öncü argues that those in the middle strata in Istanbul have progressively preferred more homebased lives, in their sterilised, orderly and clean quarters, and points to the crisis that the middle classes experience in the era of globalisation, rightly arguing that they feel threatened by this phenomenon and liberalisation:

Integration into the global economy often strengthens the upper segments of the middle strata at the expense of worsening conditions for the lower-middle class, who are faced with the prospect of downward mobility. Global cultural flows which erode distinctions of high and low culture progressively undermine the symbolic capital upon which a distinctive middle-class way of life is based.

So the markers of distinction are now defined by a variety of social strategies and cultural practices geared towards the ideal home. Öncü suggests that

...our 'ideal' home has a money sign attached to it. The significance of contemporary global myths resides in conjuring dreams as commodities, to be bought and sold. What has travelled across cultural borders to Istanbul is the ideal home as a commodity, laden with mythical content through the language of an increasingly globalised advertising industry.

Interestingly, a shopping centre is what the inhabitants of such residential sites desire as a sign of middle-class consumerism. Sencer Ayata's chapter in this volume also suggests that women's role in the making of the middle class and in marking the distinction of the middle-class home, family life and lifestyle is central in the 'hierarchy of taste', while men determine the position in the 'hierarchy of wealth'.

It is possible to argue that women have taken over shopping from men in the big cities, just as they pay the bills and do the school trips (Özbay, 1991). Shopping has become part of homemaking and domesticity, especially for the upper and middle classes. This fact could be correlated with the rising number of women car drivers who can go to city malls unescorted. Gumpert and Drucker (1996, p.6) also state that the car becomes the vehicle of salvation for women. The private car is a means for them to move around the city more safely, and shielded from its influences.

Women's access to the household money has also been modified through new practices. Middle-class women can obtain credit cards through their husbands' accounts, giving them both freedom and accountability. In contrast, in the lower income groups women usually function as the budget-makers, and try to distribute limited income according to the various needs of the family and household.

In contrast to the traditional division of labour in Turkey, with shopping being considered men's work because it concerns public space, the modernised middle classes - internalising the Western division of labour, in which men are 
expected to do paid work and women unpaid housework - now consider shopping to be a housework chore, and therefore assigned to women. Falk and Campbell (1997, p.169) suggests that shopping is mainly a feminine activity, degraded by men. Men and women have different approaches to shopping: women take a shopping trip, while men go shopping for specific needs; women experience shopping as a leisure activity, while men define it in a 'work frame'. This also applies to the Turkish urban middle class.

The mall is a secure, legitimate space for women, which makes shopping both functional and recreational. It has always been the responsibility of women to enhance the status of the family, and shopping is a new facet of this chain of statusmaking activities. Women appear to shop as individuals, although they actually shop for the household, where they maintain and reproduce the social status through their purchasing. Weekends and nights are family shopping times, in which women exercise certain power over budget decisions and over their husband's time. Women use shopping as a tool to involve husbands more in the daily upkeep of the family and homemaking practices. Also, through family shopping trips women have acquired the power of choice over much of what is bought, and to have access to their husband's income. On the weekend shopping trip, usually women fill the basket and men pay the money.

Through newspapers' consumer rights and shopping information pages, and the emergence of consumer advice bodies and associations, ${ }^{8}$ the consumer is constructed as an agent of modernity, and shopping sites become arenas of assertiveness for women. A traditional housewife who has little contact with the outside world can, for example, use the shopping encounter as an area in which to assert herself, by returning a faulty product to the shop.

\section{Malls as democratised social settings}

Historically, the Western mall marks the shift from an elite to a mass form of consumption, and is a counterpart of mass democracy, according to Miller (1995). The elements of fantasy, excess and spectacle create an illusion of mass participation and global 'citizenship' (Miller, 1995). According to Shields (1992), the mall provides 'realms of negotiation and empowerment' for the participants.

Shopping in these new urban sites is a total experience for women, including buying, seeing, strolling and eating. It is a space in which to enhance one's collective imagination. The mall is not only for the consumption of goods and services, but is also a place where one shops and constructs and feeds one's imagination of better lifestyles.

These sites can also be considered temples for collective imagination, where sacred, overwhelming, monumental physical construction dominates. It has an aura. You feel you are a part of it. The rich, modern and luxurious landscape enhances your sense of belonging to the urban. By visiting these shopping centres you feel as though you belong to the upper socioeconomic classes, who have access to all these goods and sites. Contrary to the small-shop experience, in which you are expected to purchase things, here you can just hang around, and 
still feel included. These sites are accessible to people of all socioeconomic groups. The mall is also a family recreation place, a meeting place for youngsters, somewhere they can hang around in. Many parents think the mall safe for their children because at least they know where they are. It is a closed and controlled space in which the young can learn to mix with the opposite sex and be assertive in public space.

On the other hand, malls present a hygienic, sterile, institutionalised environment, one that is well lit, well heated or cooled, in which the relationship between buyer and product is independent of shop assistants. They present a controlled and non-threatening environment to the shopper, 'who can familiarise freely with an item, recognise the need and imagine his/her life with the product' (Gumpert and Drucker, 1996, p.125).

Inside the shops, the counter is abolished and there are various types of display. The absence of a salesperson behind a counter makes the relationship with the goods more direct, the ability to choose being accompanied by an invisible influence to buy. By contrast, in the small shop the process of shopping is mediated through the shop assistant in a more direct, personalised and emotional way. In malls, there is intense energy dispersed into objects of desire rather than interpersonal contact and interaction. In this sense, malls are places where women are relatively free from harassment, unlike when shopping in the street, which still carries a stigma, as a public place. Historically, the 'public woman' has been associated with the non-respectable, the prostitute, segregated from the respectable woman. Women of the streets, street-walkers, were prostitutes, because the open street, with its lack of boundaries and its availability to all, was precisely what created 'promiscuity' in every form. As Gumpert and Drucker (1996, p.6) maintain, women in public places were not only at risk when in the streets, but created risk to themselves and social order more generally.

Connotations surrounding women and the street for centuries characterised women as commodities rather than consumers. In some cultures, the 'good woman' did not venture out into the public realm unchaperoned, as 'nice girls' were kept off the streets and close to home, with the fear that their virginity or virtue or both would be endangered. Women who ventured out were considered street-walkers, belonging to the street, their private lives on display. According to Franck and Paxson (1989), when women are in public spaces they are still defined and perceived in terms of their sexuality, a private role they are never free of. Being on the street has similar, if not worse, connotations for women in Turkey. It is no surprise that, for example, women take a child or a friend along with them when they go shopping. With company, not only does a woman's access to the public become easier - easing the granting of permission from husband or father but she also communicates the message that she is virtuous and inaccessible to men.

The mall, on the other hand, provides a legitimate use of urban space for women. It is a place in which everything is under the scrutiny of spectators. It is a 'closed open space' in which everything is to be viewed and controlled. Wilson (1992, p.6) argues that the city offers women freedom along with risk: 'woman is present in cities as temptress, as whore, as fallen woman, as lesbian, but also as virtuous woman in danger, as heroic womanhood who triumphs over temptation 
and tribulation'. The shopping mall is perhaps one chance for a woman to match the male flâneuras a free wanderer. As Aksoy (1997) says, the mall is a global town; therefore, we should ask to what extent shopping is an emancipatory practice for women, and to what extent a woman can be free in such an image-directed town. The quotation by the anthropologist Marc Auge (cited in Aksoy, 1997. p.111), from the brochure of the Metro Centre in Gateshead in the Northeast of England - which has more than 28 million visitors a year, 6000 staff and 360 shops in a setting designed according to a town plan and family atmosphere - is the most telling:

The shopping malls are not confined to space and time anymore. The roots of these centres - in which only the present time is lived - are not in the soil or in a specific geography but in the administration of display, public relations and marketing. Here is an excess of space: The same person can be in Texas, Tokyo, California and Gateshead at the same time. As far as their credits last, people can leave their social identity in the car park and enjoy the personal taste of loss of identity and role playing inside the malls.

In a sense, the mall is a place where one can magically shed a social identity and take on a universal one. Women shoppers can usually get over their feeling of insecurity in a public place through a confidence in the information they gather about goods' quality and price. Also, women usually take time window-shopping, as they feel themselves to be on the scene while strolling in the mall. Hence the mall provides integration for women into capitalist society through individualised gratification rather than communal-societal action.

In Turkey, as elsewhere, the mall seems a place in which differences of class, age and gender do not matter; indeed, it is a democratised space when compared to shopping sites such as the bazaar, the boutique or the department store, not only for the shoppers but also for the staff.

Our interviews with shop managers show that parallel to alterations in the work setting, there have also been changes in the work culture: management ideology, selling strategies and the social conduct of the shop assistants towards shop managers and customers. The shop assistant of a small shop has been transformed into the salesperson in the mall, with a relatively gender-and class-neutral identity. New managerial ideologies at the shop define shop assistants as members of a work team in uniforms carrying the corporate logo. They implement training programmes to impose on the sales process codified, routinised behaviour and speech that necessitates less interaction with the shopper.

According to Reekie (1992), the department store's careful targeting of a female clientele has been replaced by a post-modernist emphasis on diversity and eclecticism. This reformulated consumer culture reaches out to new categories of clientele and searches for new markets among children, teenagers and men. While women's work associated with family shopping has been relegated to more mundane sites of consumption, such as supermarkets, neighbourhood shops and suburban shopping centres, sites of leisure retailing are less feminine in character and target men as customers. In Turkey, although malls target mainly female customers, the pool-rooms recently introduced are designed to appeal to a male clientele. 


\section{The gender and class dimensions of shopping encounters}

In an earlier project about women office workers and shop assistants (Cindoğlu and Durakbaşa, 1996), we were interested in the different types of discrimination women experience in the area called 'pink-collar occupations', a recently expanding area of female employment parallel to the development of the service sector both in the West and in Turkey. These are also defined as consumer contact occupations, in which stereotypical feminine qualities, such as beauty, attractiveness, docility and service to others, become important assets.

This research was carried out using focus groups and group and individual interviews with office workers and sales assistants in Ankara and Istanbul in 1996. We were interested in focusing on three inter-related issues: social perceptions of women's office and sales work; women's self-perceptions in these jobs; women's coping strategies in the face of harassment.

Office and sales work are feminised occupations involving gendered expectations of job definitions. In our research, we focused on the influence of a number of factors: the organisation of work, in terms of office hierarchies, the scale of the shop, the social-cultural milieu and codes of the workplace, gender stereotypes, and the workers' social class and background. One important question that we dealt with was the extent of the impact of the growing consumer capitalism and the dynamism and proliferation in the area of distribution, marketing and consumption on the internal organisation of shops and the labour force. Inspired by Benson (1996), a study of the history of the department store in America, 1890-1940, we wanted to evaluate how social change was reflected in the shop setting and in the social drama of the actors in this setting: the shoppers, the saleswomen and the shop managers.

Benson's study indicates that there has been a shift from a more feminine workplace culture, which emphasised personal service to shoppers, prevalent in small shops run by women to a more masculine business mentality and culture. There has been a corresponding change in the interior design of department stores and hypermarkets to an emphasis on open shelving, tempting arrays of goods, and self-service, in which the display of the goods in an impersonal setting becomes more important.

With England as their subject, Mackie and Patullo (1977), suggest that the pattern of employment in shops has changed drastically, so that in supermarkets the old idea of the importance of service, with its skills, has been entirely replaced by the importance of displaying goods, encouraging a rapid flow of customers through the store, and replacing goods so that the greatest possible tempting array is always visible. In all this, the role of the woman shop assistant has been reduced to that of shelf-stacker and check-out operator.

To what extent is this picture valid for Turkey? Is the status of the shop assistant falling or rising? In our interviews we witnessed a conscious attempt in the managerial ideology of the shops to define the workers in the shop as satıs elemanı ('salesperson'), much less gendered than the term tezgahtar kız ('shop girl'), sometimes disparaged as tezgahtar parşası ('counter rubbish'), hinting at low gender and class status. Shop managers openly told us that they preferred salespeople 
with high-school education and who came from 'well-behaved', preferably middleclass, backgrounds. There are also training schemes that socialise shop workers into the culture of the mall, in which standardised behaviour and etiquette is taught. Along with such an 'egalitarian' managerial ideology, however, we also observed a high turnover and discriminatory practices, such as employing young people short-term, then dispensing with them. Managers clearly indicated that they did not want women who were married or who had children, as they would not be able to adapt to the working hours and conditions of the shop, mainly involving a 12-hour working day, six or seven days a week.

A recent study by the Sosyal Eğitim ve Danışmanlık Şirketi, carried out in 37 shops such as Bennetton, Mudo and Bata, found that 54.7 percent of shop managers were women. This is a very significant number, and our interviews also show that women in this sector are very career-oriented, and work with a real 'protestant work ethic'. Our interviews show that most women in managerial positions in shops perceived the growing area of retailing as suitable for upwardly mobile women. Other findings show that among sales workers, women make up 52.5 percent of the total. The striking figure is the presence of women as cashiers ( 83.9 percent). ${ }^{9}$

Our findings also show that women experience a certain type of discrimination in recruitment and promotion. Young unmarried women are particularly preferred as shop assistants, due to their short-lived work prospects. Among office workers, although state employees benefit from some paid maternity and childcare support, the private sector prefers unattached women without household responsibilities. Along with these job-market characteristics, women also experience different forms of sexual harassment, yet they lack formal and institutional redress. In such cases, managers tended to keep harassed saleswomen out of sight, employing them behind the scenes.

Women try to exploit some of the elements of the traditional patriarchal culture and modernist egalitarian ethic to their benefit in dealing with sexual discrimination and harassment in the workplace. Among these defensive strategies, 'de-sexing' the work environment is prevalent. Women are conscious about their appearance, and dress non-provocatively. Another strategy is to utilise kinship codes in the office environment to get respect. They utilise family connections and relations to deal with harassers: one of our informants had threatened the harasser by mentioning acquaintances in high government office.

Encounters between women shop assistants and women shoppers are worth exploring, in order to see the role of gender and class dynamics in the drama of shopping. Douglas (1997, pp.18-19) suggests that 'shopping sites are arenas of cultural contest', with shopping practices showing signs of 'standardised hates', so that 'choosing commodities is choosing between cultures, choosing one and rejecting the others'. We observed that women shoppers, in disparaging products, usually applied strong categories to differentiate the product from themselves, such as, 'How disgusting, fit for a village girl'. In that way, not only do they reflect their dislike of the product, they do so in such a manner as to emphasise their class status, while devaluing the shop assistant as well.

Another type of encounter in the shopping scene takes place between the 'expert' housewife and the young, usually inexperienced, salesperson. The 
traditional role of housewife in Turkey includes all kinds of homemaking talents, among them cooking, cleaning and sewing. The Girls' Institutes, as well as People's Centres of the Ministry of Education throughout Turkey, offer extensive formal and informal education to prospective housewives in cooking and sewing. So women who are already expert needlewomen but prefer to buy ready-made clothes are the most critical shoppers. The encounter between the craft-trained housewife and the saleswoman usually takes the form of a contest over how much they know about the product: for example, the cut, style and quality of a garment are discussed obsessively. The contest is as much about the denigration of the saleswoman as the product itself. The hierarchy of age is quite strong in Turkey, and the culturally determined hierarchy among women is likely to be reflected in their conduct towards the usually younger shop assistants. Shop assistants take their revenge by mocking their adversaries over their incompetence in some other area. For example, in our research a shop assistant obsessively told the story of how she teased one of her clients when she used the word minyon (meaning 'small', from the French mignon) as milyon ('million'). She giggled for quite some time at the customer's ignorance. Class conflict is also lived out in such dramas.

We noticed that women in stigmatised occupations, such as secretarial, sales or other consumer-contact occupations, are more aware of their gender because of the gender-typing of occupations, and so react more directly and spontaneously to incidences of harassment. These occupations are perceived as having the connotation of 'sexual service to men' in the public unconscious and male fantasy. Most of our informants related their unease about it. It was interesting to note that women can be quite spontaneous and outspoken about the degradation of their sex status and identity.

In the mall, shop assistants identify themselves as representatives of the various chainstores and labels, and perhaps feel more secure in such an impersonal and regulated work setting. However, workers in fast food restaurants usually work in less secure conditions. The women shop assistants emphasised training as the most important asset in the improvement of their occupational status, professionalising 'service to others' as part of paid labour in a cultural context where these are normally demeaned. Recent developments in the retail sector and management ideologies have successfully rendering the job of 'selling' and 'serving' as a profession requiring certain qualifications.

\section{Conclusion}

Shopping practices in Turkey have gone through a great transformation, and we believe that the rise of the malls and hypermarkets played a significant role in this. In this chapter, we have described changes in the homemaking activities of the middle-class housewife and emphasised the gendered aspects of shopping. We believe the mall has afforded, especially for women of the middle and upper classes, the opportunity for a 'fictive' global experience and the freedom of a wanderer in a public place.

We have also analysed shopping in terms of certain dramas that take place between female shoppers and shop assistants. In our view, there is always a 
struggle involving class and age differences in the process of assessing goods, selling and buying. We have described the working conditions of shop assistants and hinted at various forms of sexual discrimination that female shop assistants face. However, our study also showed that the status of shop assistant is rising with the rise of the mall, especially with rise of standardised in-service training and the more gender-neutral work culture of the mall. In conclusion, the diverse venues for shopping in post-1980s Turkey present us with shifting visions of gender and class in a rapidly changing society.

\section{Notes on chapter 3}

1 According to the 1990 census, 59 percent of the population lived in urban areas; Istanbul is the most populous metropolitan area, with 12.9 percent of the total population of Turkey; Ankara is second, with 5.7 percent; Izmir is third, with 4.8 percent. The annual rate of population increase between 1985 and 1990 in Istanbul was 44.78 percent, in Ankara 21.28 percent, in Izmir 30.14 percent. According to the State Statistics Institute Income Distribution Research Report of 1994, 27.5 percent of the national income is consumed in Istanbul, 40 percent in the five big cities of Istanbul, Ankara, Izmir, Adana and Bursa. That means that sections of society with the budgetary means to shop in malls and hypermarkets have increased in these cities. (Sönmez,1997, p.101)

2 In Istanbul, which has the most unequal distribution of income, the most wealthy 20 percent of population receives 64 percent of the city's income (Sönmez,1997, p.102). The poorest 20 percent gets only 4.2 percent. Ankara and Izmir show similar findings; in Ankara, the richest 20 percent gets 47.9, in Izmir the same proportion of the population gets 54.2 percent. The poorest 20 percent gets 5.7 percent in Ankara and 5.9 percent in Izmir (Sönmez, 1996, p.135; Sönmez, 1997, p.104).

3 In terms of the durable goods that Istanbul households own, it is striking to note that 97.4 percent have refrigerators, 83.6 percent hoovers, 73.4 percent washing machines and 90.6 percent colour televisions. (Sönmez, 1996, p.138).

4 A new offer from the banks is the taksit card, which allows the holder to pay in instalments when buying from shops that have an agreement with the specific bank. There is also a card issued by a group of different shops that offers payment options and promotions.

5 Domestic corporations in the country, such as Koç, Sabancı, Tekfen, Doğuş, Sezginler and Okumuş, have either entered into the retail sector on their own or helped multinational retailers enter the market by associating with them, either through licensing agreements or joint ventures, as in the cases of Koç Holdings, which owns Migros, or Sabancı Holdings, which has a joint venture with Carrefour.

6 In an interview, the president of Türkiye Bakkallar Federasyonu (the Turkish Federation of Grocers) said that customers in rural neighbourhoods and urban slums were 30 trillion lira in debt to grocers, who also function as a neighbourhood bank. Borrowers cannot be traced, as they are mostly recorded informally as yukardaki teyze ('the aunt on the top floor'), sarn sachl bayan ('the woman with the blond hair'), maliyeci bey ('the accountant gentleman') etc. (Radikal, 29 April 1998, p.12). 
7 'It is very easy to join the Oriflame chain, and Oriflame provides all kinds of support for your success. You are under an Oriflame distributor, and an Oriflame Starter's Kit is given to you. There are a number of products and publications in the Starter's Kit. These publications are a great help in showing how to develop your business. Your success is limited only by the targets and effort you specify for yourself. Choose great targets for yourself! You will see that many of your dreams will come true in time.' (Translated from the Starter's Kit, Oriflame Başarı Planı.)

8 In the Milliyet Shopping Catalogue of 19 June 1998, Emre Aköz, editor of the shopping supplement of the magazine Vitrin wrote, 'The shopping activity has developed so much that it becomes a subject for newspaper supplements or magazines. Vitrin, which has reached readers for more than 80 weeks now, is a good example of this; besides we try to have this magazine in your hands every season. The speciality of these publications is that they are not merely catalogues. They investigate shopping as a social activity beyond 'what to buy?', 'where to buy?' and 'how much?', taking into consideration gender relations, culture, recreation and stress... I hope you will benefit from our Shopping Guide. If we can provide you with a chance to follow the new trends and fashion as well as possibilities to buy good quality at a cheap price, we will be happy...'

9 According to the same research, almost 80 percent of the managers are between the ages of twenty-three and forty, only 9.45 percent are above forty, and 7.7 percent are between the ages of twenty and twenty-two. The majority ( 56.4 percent) are quite young, between the ages of twenty and thirty. The findings are not divided according to gender (Radikal, 25 February, 1998).

\section{References}

Aksoy, Asu (1997), 'Küresel Kasabadaydım', İstanbul Dergisi 22, pp.111-12.

Ayata, Sencer and Ayşe Ayata (1996), Konut, Komşuluk ve Kent Kültürü, T.C. Başbakanlık Toplu Konut İdaresi Başkanlığı, Ankara

Benson, Susan Porter (1986), Counter Cultures: Saleswomen, Managers, and Customers in American Department Stores 1890-1940, University of Illlinois Press, Chicago, IL

Cindoğlu, Dilek and Ayşe Durakbaşa (1996), İsyerlerinde Cinsiyete Dayalı Ayrımcılı ve İsverenlerin Kadın Çalışanlarnna Karşı Tutumu: Büro ve Mağaza Çalışanlarna Derinlemesine Bir Bakıs (Discrimination at the Workplace: An In-depth Approach to Women Clerical and Sales Workers), project report, Kadının Statüsü ve Sorunları Genel Müdürlüğü, Ankara

Dökmeci, Vedia. (1989), 'Batı Alman Şehirlerinde ve İstanbul'da Yaya Ticaret Aksları Planlaması', Yapı 94, pp.36-40

Douglas, Mary (1997), 'In defense of shopping', in F. Pasi and C. Campbell (eds), The Shopping Experience, Sage, London, pp.15-30

Duben, Alan and Cem Behar (1991), Istanbul Households: Marriage, Family and Fertility, 1820-1940, Cambridge University Press, Cambridge

Falk, Pasi and Colin Campbell (1997)(eds), The Shopping Experience, Sage, London

Franck, K.A. and L. Paxson (1989), 'Women and urban public space: research, design and policy issues', in E. Zube and S.G. Moore (eds), Advances in Environment, Behavior and Design 2, pp.122-46, Plenium, New York, NY 
Ger, Güliz and Russell W. Belk (1990), 'Measuring and comparing materialism crossculturally', Advances in Consumer Research 17, pp.186-92

Gumpert, Gary and Susan J. Drucker (1996), Voices in the Street: Explorations in Gender, Media, and Public Space, Hampton Press, New York, NY

Gürbilek, Nurdan (1993), Vitrinde Yasamak: 1980'lerin Kültürel İklimi, Metis, Istanbul

Hür, Ayşe (1997), 'Alışveriş Merkezleri', İstanbul Dergisi 22, pp.105-107

Işın, Ekrem (1985), '19. Yy.'da Modernleşme ve Gündelik Hayat', Tanzimattan Cumhuriyete Türkiye Ansiklopedisi, İletişim, Istanbul, pp.538-63

Kozanoğlu, Can (1995), 'Demokrasinin Beşiği Süpermarket mi?' Cogito 5, pp.21-3

Mackie, Lindsay and Polly Pattullo (1977), Women at Work, Tavistock Women's Studies, London

Miller, Daniel (1995), 'Anthropology, modernity and consumption', in Daniel Miller (ed.), Worlds Apart: Modernity Through the Prism of the Local, Routledge, London and New York, pp.1-42

Öncü, Ayşe (1994), 'Middle class life styles in the cultural geography of post-infitah Istanbul', paper presented at the workshop 'Local Cultures in Global Cities', Boğaziçi University, Istanbul

- (1997), 'The myth of the 'ideal home' travels across cultural borders to Istanbul', in Ayşe Öncü and Petra Weyland (eds), Space, Culture and Power New Identities in Globalising Cities, Zed, London

Özbay, Ferhunde (1991), 'Changes in women's activities both inside and outside the home', in S.. Tekelı (ed.), Women in Modern Turkish Society, Zed, London

Özbay, F. (1991), 'Türkiye'de Aile ve Hane Yapısı: Dün, Bugün, Yarın', Mübeccel Kıray'a Armağan. Marmara Üniversitesi Dergisi Özel Sayı, Istanbul

- (1996) 'Evler, Kadınlar ve Evkadınları', in Emine M. Komut (ed.), Diğerlerinin Konut Sorunlar, Habitat II ön Konferansı, TMMOB Mimarlar Odası, Ankara

Radner, Hilary (1995), Shopping Around: Feminine Culture and the Pursuit of Pleasure, Routledge, London and New York

Reekie, Gail (1992), 'Changes in the Adamless Eden: the spatial and sexual transformation of a Brisbane department store 1930-90', in G. Reekie, Temptations: Sex, Selling, and the Department Store, pp.170-94, Allen and Unwin, Sydney

Sayılı, Tuba (1992), Alışveriş Merkezlerinin Gelişimi Sınıflandırlması ve Tasarımın Etkileyen Faktörler, Mimar Sinan Üniversitesi, Mimarlık Fakültesi, Yüksek Lisans tezi, Istanbul

Serpil, Ahmet, R. Nişel, A. Ağaoğlu and Y. Karapazar (1998), Bakkaliye Sektörünün Profili ve Rekabet Olanaklar, İstanbul Ticaret Odası, Istanbul

Sönmez, Mustafa (1990), Türkiye'de Gelir Eşitsizliği, İletişim, Istanbul

- (1996), İstanbul'un İki Yüzü: 1980'den 2000'e Değişim, Arkadaş Yayınları, Ankara

- (1997), 'İstanbul'un Hipermarketleri', İstanbul Dergisi 22, pp.101-4.

Shields, Rob (1992), Lifestyle Shopping: The Subject of Consumption, Routledge, London and New York

Tokatlı, Nebahat and Yonca Boyacı (1997), 'Internationalisation of Retailing in Turkey', New Perspectives on Turkey 17, pp.97-128.

- (1998), 'The State and the Corporate Private Sector in the Recent Restructuring of Turkish Retailing', New Perspectives on Turkey 18, pp.79-111.

Toprak, Zafer (1995), 'Tüketim örüntüleri ve Osmanlı mağazaları', Cogito: Dünya Büyük Bir Mă̆aza 5, special issue, Yapı Kredi Yayınları, Istanbul, pp.25-8

Wilson, Elizabeth (1992), The Sphinx in the City: Urban Life, the Control of Disorder, and Women, University of California Press, Berkeley, CA 